\begin{tabular}{|c|c|c|}
\hline $2002,65-74$ & $\begin{array}{c}\text { ETHICS IN SCIENCE AND ENVIRONMENTAL POLITICS } \\
\text { ESEP }\end{array}$ & Published September 26 \\
\hline
\end{tabular}

\title{
Wisdom with justice
}

\author{
Celia Deane-Drummond*
}

Department of Theology and Religious Studies, Chester College, Parkgate Road, Chester CH1 4BJ, United Kingdom

\begin{abstract}
This paper explores the way we make environmental decisions, especially in the context of heavily contested issues such as GMOs. It suggests that as well as attention to particular consequences of action, due consideration needs to be given to the motivation and attitudes of the agents concerned, in other words, to virtue ethics. The values behind environmental decision-making are predicated on religious as well as philosophical assumptions. I argue that not only is it important to identify religious mandates for environmental action through models such as that of kinship, but also that exploring the wisdom tradition from a Christian perspective can serve to clarify ways forward where decision making is difficult. In the Christian community itself a recovery of wisdom and justice as virtues can serve to raise the importance of environmental concern, since it is rooted in an understanding of God as creator and the idea of natural law. The concept of justice complements that of wisdom in that it facilitates an objective stance according to certain principles of equity.
\end{abstract}

As environmental pressures on our planet continue to increase, there is a new urgency to find ways forward in making practical decisions. The difficulty in making such decisions is well known, given the diversity of interests and conflicting assessment of priorities in each case (Huxham \& Sumner 2000: ix-xi). There are a number of possible underlying causes of these difficulties. In general, there has been a bias towards constructing the framework of decision-making in terms of specific cases, judged in terms of the relative risk or benefit of a particular action(s). ${ }^{1} \mathrm{~A}$ case-by-case pragmatic approach certainly yields results that are specific for the issue in hand, but is not the only way of describing ethical choice. I have suggested that in the particular situation of GM Os such a framing assumes a consequentialist approach to ethics that is not necessarily sufficient, given that risks are in many cases not readily quantified and the benefits more often than not directed to a particular group or community (Deane-

\footnotetext{
${ }^{1}$ I am using the term 'risk' in a traditional, rationalist sense; though as Donald Bruce suggests, there have been moves away from this definition in more recent discussions. See Bruce (2001).
}

*E-mail: c.deane-drummond@chester.ac.uk
Drummond 2001:119-28). ${ }^{2}$ If environmental risks are unclear, such as is often the case with genetically modified (GM) crops, then decisions will either take place on the basis of supposed benefits, highlighted as general advantages by a particular interest group, or the precautionary principle will be invoked in order to delay action until such time as the risks are quantified. The precautionary principle is sometimes defined as 'a strategy for dealing with environmental risk and uncertainty, which guides us to act cautiously and embark on a systematic programme of research to improve our understanding of the costs and benefits of particular actions' (BM A 1999:17). There are a number of difficulties associated with this type of precautionary approach (Merritt \& J ones 2000:84-87). In the first place there are different assessments as to the degree of environmental risk in defining when the precautionary principle will take effect. Secondly, the extent of environmental risk is itself highly contested (Lash et al. 1996). Of course there are some who interpret the precautionary principle as the basis for inaction unless positive damage is proven not to be the case. Donald

\footnotetext{
${ }^{2}$ I am not implying that consequences should never be taken into account, rather than viewing the problem just in terms of consequences alone may miss out other aspects of ethical insight that need to be taken into account.
} 
Bruce has discussed the competing visions of precaution (Bruce 2001). The language of precaution, rather like that of sustainability, can be filled out with different contents depending on the players involved. Such a discovery implies that we need to look behind the language to the motivation of those who are using such language. This is the province of virtue ethics. I hope to show that one way of filling out what a virtue ethic might look like from a Christian perspective draws on a rediscovery of the importance of wisdom. Wisdom in addition includes the idea of prudence, or practical wisdom, which in its turn includes the concept of precaution. Precaution thus becomes both situated and critiqued in the context of a wider Christian vision of reality.

The philosopher Mary Midgley has also identified another problem when it comes to making decisions about the environment. She suggests that even if the risks are well known, inaction will still follow if the imagination is not sufficiently engaged. In other words, bald scientific facts about the perilous state of the planet are insufficient to motivate action or decisionmaking in its favour (Midgley 2001:188). While she sees that there are signs that people do care about the earth, the reason for this is not so much the threat of environmental collapse, as a renewed sense that we are part of the earth and have evolved from it. Midgley believes that Gaian thinking can serve to challenge acute individualism and anthropocentrism, which she identifies as the heart of the problem (Midgley 2001: 171-174). Gaian thinking is certainly suggestive of a more holistic understanding of reality. However, as I have argued elsewhere, there are theological and ethical problems associated with a Gaian approach to the world (Deane-Drummond 2001: 165-183). For example, in its more idealistic forms, Gaia seems not only to equalise the place of humanity in relation to other species, but also to put bacteria and blue green algae at the top of the pyramid. Furthermore, if Gaia is held to be a stabilising global system, it could be used to support environmental abuse, rather than the opposite.

I suggest that Midgley is, nonetheless, correct in searching for alternative ways of approaching the way we think about the earth and identifying underlying values that are behind our decision-making. A common Christian response to these difficulties has been to advocate the ideal of stewardship (Berry 2000: 25). While this can take us some way in making responsible decisions, the will to change remains largely untouched through this motif alone. Furthermore, stewardship often implies management of the planet, which in itself can be suggestive of a somewhat anthropocentric epistemology. While it is preferable to other biblical motifs such as the idea of kingship, it still tends to be hierarchical in its assumption that nature is somehow 'below' the order of humankind, human are 'stewards' over against the natural world. From a historical perspective the interpretation of the notion of stewardship is problematic, associated with ideas about dominion and dreams about repairing the natural world through human ingenuity (Bauckham 2000: 100-102). A third alternative is that of kinship, developing the notion that all creatures are in some sense part of who we are as human beings. Such a view is not only consistent with evolutionary science, it also articulates an important biblical principle, namely that the creatures of the earth, including humans, give glory to God, rather than human beings alone (Bauckham 2002).

In this paper I suggest that one way to develop an ethic towards the natural world that highlights the notion of kinship is through a recovery of the idea of wisdom. Such a recovery has a number of advantages. Firstly, it challenges the idea that science is the only way of knowing, instead wisdom invites a broader frame of reference compared with the fragmented problem solving approach characteristic of much of modern science (Deane-Drummond 2000:5-14). In the second place it connects with the philosophical trend in ethics that focuses on agents and attitudes rather than actions, known as virtue ethics. In the third place wisdom draws on ancient theological traditions and resonates with theological imagination. As such it can offer a vision that serves to inspire appropriate action. In the fourth place wisdom has ethical outcomes through its association with the cardinal virtues of practical wisdom or prudence, justice, temperance and fortitude. In this paper I focus specifically on the 2 virtues of prudence and justice and how they might be expressed in practice, as they seem to me to be of particular relevance to environmental decision-making.

The special attention to consequential ism in environmental decision-making may seem somewhat surprising given the strong move in contemporary philosophy to recover an alternative approach to ethics that stresses moral character, namely virtue ethics (Crisp \& Slote 1998, Hursthouse 1999). On the other hand, a purely deontological approach that frames particular issues from theological norms may seem out of touch with secular ethical debates (Deane-Drummond et al. 2001:35-36). Virtue ethics, by focusing on the agent, rather than just the possible outcomes of specific ethical dilemmas in isolation, encourages ongoing moral attention that serves not only to sustain human resilience in times when decision making is difficult, but also to challenge all parties involved to re-examine their attitudes. Virtue ethics is characterised by being agent centred, rather than act centred, putting emphasis on goodness, rather than rights, duties or obligations, even positively rejecting the idea that ethics can 
be codified in rules. Yet this does not mean that virtue ethics is not interested in particular actions, or for that matter the consequences of those actions. Rather, the fundamental ethical question of what I should do is expanded into related questions about who I am, who I should become and how I should get there (Keenan 1998: 84).

\section{THEOLOGICAL WISDOM}

What is meant by theological wisdom? ${ }^{3}$ Wisdom, by definition, is hard to define with any precision, as she appears in various guises in scriptural and traditional texts. Nonetheless, even the early 17th century natural scientists, such as J ohn Ray, found the motif of wisdom expressive of the way they hoped to discover traces of God in the natural world (Ray 1977). Ray was reluctant to attribute more to wisdom than a trace or reflection of the mind of God in creation. Other theologians, writing from an Eastern Orthodox perspective, have developed a Sophiology that places Wisdom integral to the being of God. ${ }^{4}$ It seems fair to suggest that scriptural texts point in this direction. In the Old Testament book of Proverbs, for example, Wisdom is personified as the one who works alongside God in the creation of the world. ${ }^{5}$

Wisdom, according to the book of Wisdom, is 'intelligent, holy, unique, manifold, subtle, active, incisive, unsullied, lucid, invulnerable, benevolent, sharp, irresistible, beneficient, loving to man, steadfast, dependable, unperturbed, almighty, all-surveying' (Wisdom 7:22-23). It could even be said that some wisdom books, such as the book of Ecclesiastes, echo to some extent the approach adopted by contemporary philosophers advocating virtue ethics (Christianson 2002). Wisdom in the Old Testament is also something that is learnt in the human community, through experience in practical decision-making in family life, education and observation of the natural world. What are the possible ways to find wisdom? The book of Proverbs invites his readers to 'Go to the ant, you sluggard, See its ways and be wise' (Proverbs 6:7). The seeing is not so much simple observation of information about the ants, as perceiving the inner distinctive core of what it is to be

\footnotetext{
${ }^{3}$ I have discussed this idea in detail previously in DeaneDrummond 2000

${ }^{4}$ Sergii Bulgakov is a good example, though it should be noted that his views on wisdom have been criticised by other orthodox scholars, such as Vladimir Lossky (For discussion see Deane-Drummond 2000: 78-92)

${ }^{5}$ The developing interest in wisdom literature among Old Testament scholars bespeaks of a relative neglect of this tradition, see Deane-Drummond 2000: 15-22
}

an ant (Habel 2002). In other places in wisdom literature the word 'to discern' (bin) is used, often following the act of seeing, to describe the process of becoming wise. Hence discernment is integral to what it means to gain wisdom. Discernment considers a range of options, but ultimately lights on 'the way', understood not just as the alternative between 2 paths, but also as the inner driving characteristic of something (Habel 2002). This, it seems to me, is particularly important as it locates discernment as that which correctly identifies the inner core of something, that itself is expressive of wisdom. Significantly, in the book of J ob 28 the characteristic of finding wisdom also applies to God, as God 'sees' the different components of creation (Habel 2002). On this basis it is possible that Proverbs 8:22 means not that God created wisdom, but the more common understanding of the word qana, namely God acquired wisdom. This reinforces the suggestion that I have made elsewhere that an essential characteristic of God is that of wisdom (Deane-Drummond 2000: 131-137). M oreover, there appears to be a dialectical relationship between God and the world in the creative process. God creates through wisdom, but God discovers wisdom in its turn in the created order. This does not preclude the primary focus of the Christian tradition on God relating to the world through overflowing love. Rather, creation is in love, but through wisdom. This sapiential understanding of God's relationship to the world has common ground with some other religious traditions and serves to challenge the individualistic way we think about ourselves and in its place situate humanity in the wider cosmic community of life (Nasr 1996: 205). ${ }^{6}$

The Christian tradition, nonetheless, develops this perennial philosophy in a way that is distinct, namely through the notion of the wisdom of the cross (DeaneDrummond 2000: 52-59). The cross is proclaimed as the ultimate expression of the wisdom of God (1. Cor. 1.8-2.5). This aspect of wisdom might come as something of a shock, yet it serves as a reminder of the suffering and cruelty evident in the natural world and in human relationships. The wisdom of the cross announces the fact that such suffering is not outside the concern of God who is in Christ, rather the crucified one takes on such suffering in solidarity with the earth. The savage loss of species could be said to be a loss in God, for it is a loss in abundance of relationships (Larkin 2002). Nonetheless, for the Christian tradition the cross is not the last word, for its consideration is coloured by hope in the resurrection. John's Gospel

\footnotetext{
${ }^{6} \mathrm{~N}$ asr criticises the West for its focus on environmental ethics; for him a religious understanding of the order of nature needs to have a higher priority. I suggest that a shift in understanding of ordering is commensurate with a new ethical approach
} 
speaks of the Logos acting in the world in terms that resemble very closely the way Wisdom is spoken about in the Old Testament (Deane-Drummond 2003). Hence Christ as Logos is identified with Wisdom or Sophia. Yet for J ohn the cross is also the cross of Glory, for it points to a future in which all creation will be redeemed. The message of wisdom is, then, ultimately a hopeful one, even if it resists turning away from the challenge of creaturely suffering.

\section{A RECOVERY OF A WISDOM ETHIC}

While there are a variety of ways of thinking about wisdom from a Christian perspective, I have argued elsewhere that a wisdom ethic drawing on the works of Thomas Aquinas gives significant insights about the way to approach the natural world (Deane-Drummond 2000:99-107, 2002). Wisdom as theological wisdom needs to be set in the context of the 3 theological virtues of faith, hope and charity. (1 Cor. 13). Wisdom is learned, but it is also a gift from God. As gift it is given by grace, rather than through rigid adherence to the law, even though it is not separate from law. Aquinas describes the 7 gifts of the Holy Spirit as wisdom, understanding, counsel, fortitude, knowledge, piety and fear of the Lord. ${ }^{7}$ In as much as it can be learned, it can be shared by all those of good will, whether Christian or not. In this sense it is aligned with the idea of natural law. Yet divine Wisdom al so finds expression in the eternal or divine law, which for Christians is expressed in obedience to the demands of the Gospel (Eph. 1. 8-10). Hence a measure of whether an action is wise or not is in relationship to this divine law, a point made repeatedly by Aquinas in his Summa Theologiae (Cessario 2001:58-59). ${ }^{8}$ For Aquinas wisdom is one of the 3 intellectual virtues of speculative reason, the others being understanding, or grasping first principles and scientia, which denotes the comprehension of the causes of things and the relationship between them. In other words wisdom is the understanding of the fundamental causes of everything and their relationship to everything else. In Aquinas wisdom is expressed theologically, for God is the ultimate cause of all that exists in virtue of the fact that God is creator. Human wisdom is a virtue directed towards the Wis-

\footnotetext{
${ }^{7}$ The traditional formulation takes its bearings from the virtues possessed by the coming Messiah, as described by Isaiah 11:1-2, and taken up in early Christian traditions as corresponding to the gifts of the Spirit. (Cessario 2001: 205-12)

${ }^{8}$ In the light of this it might seem surprising that some moral philosophers have tended to abstract the idea of natural law from Aquinas, and ignored its link with covenant relationships. For discussion see Deane-Drummond 2002
}

dom of God, for while wisdom can be learned it cannot be grasped or used for human aggrandisement (Proverbs 16). In the fullest sense human wisdom is only possible through the gift of the Holy Spirit by the grace of God. The Christian vocation includes developing the virtue of wisdom, seeking her through obedience to God's covenant laws as well as acquiring her through education and family life.

Wisdom is closely related to one of the intellectual virtues of practical reason, namely prudence, also termed practical wisdom. Practical wisdom is particularly significant for ethics, since it sets the way individual virtues must be expressed in particular circumstances. Developing prudence is not just about one's inner attitude, though it includes this, but it is also about how this attitude is expressed in action..$^{9}$ For example, practical wisdom comes into play in discerning what is the most appropriate way of acting in given circumstances. Virtuous behaviour may, in some circumstances, be related to the means of attaining a particular goal. For example, genetically engineering seed so that it is sterile in order to force farmers to buy new seed every year could be seen as an inappropriate means in order to attain the goal of maximum profits. The goal itself may also be challenged where it eclipses other goals such as respect for the needs of the local community. In this case a form of 'prudence' would have led to the decision that sterile seed is the best way of attaining the goal, but because the goal is faulty, this leads to what Aquinas describes as 'sham prudence'. Indeed, for the biblical writers discernment and wisdom are intimately linked with the fear of the Lord (Proverbs 1.7, 2.5, 9.10 etc.). Hence, forms of discernment that act against the needs of the community amount to folly. Perhaps more accurately we could say that the goal is a partial good, for it benefits relatively few people. Hence, a virtue ethic orientated around wisdom includes the idea of consequences, but it is in relationship to orientation towards the Good, understood in terms of that which is in accordance with covenant law. A quinas also used the term 'incomplete prudence' to indicate that the good is narrowed to particular individuals. These distorted forms of practical wisdom are worth bearing in mind, since from the perspective of, for example, a biotechnology company an action could look like it is entirely prudent. However, once the wider needs of the community are taken into account, such formulation of practical wisdom is shown to be incomplete. In this scenario practical wisdom

\footnotetext{
${ }^{9} \mathrm{M}$ ary Midgley has criticised the effectiveness of prudence for motivating environmental decision-making. However, her understanding of prudence is one that relates simply to rational causes and individual self-interest, rather than being situated in a broader theological understanding of wisdom in the manner I am suggesting here (M idgley 2001:188)
} 
relates strongly to justice, which I will discuss further below.

However, virtues are more subtle in that expressing a particular virtue cannot necessarily always be described through means and ends type of analysis. What would count as behaving virtuously in the context of the practice of science and technology? While the goals of environmental decision-making and the means of attaining such goals may come under scrutiny through prudential considerations, the humility to accept that the public may have important insights into social issues, the courage to challenge developments in those cases where the opinion of local farming communities have not been taken into account, actions such as these are not readily analysed simply in terms of means and ends.

Practical wisdom includes a number of characteristics that are worth pondering in the present context. Aquinas draws on 5 areas related to knowing, namely memory, reason, understanding, aptness to being taught and ingenuity (Aquinas 1974: 55). ${ }^{10}$ Clearly reason, understanding and ingenuity all come into play in developing scientific methods that are sensitive to environmental concerns. Yet these characteristics alone are not sufficient for practical wisdom, since it includes memory as well. The ability to remember is associated with appreciation of history and tradition. The memory is used in a selective way in devising new technologies. Historically biotechnology has emerged as one more example of the way humankind engages with the natural world. However, it cannot simply be isolated from the social context of the culture of modern industrial farming (Northcott 2002). While it may not be possible to return to earlier idealised communities, in the way that Northcott seems to suggest, a deeper memory of what it means for humanity to be in relationship with the land would shift what is envisaged in terms of practical wisdom.

Aquinas identifies 3 areas of practical wisdom related to doing, namely foresight, circumspection and caution, or avoiding obstacles (Aquinas 1974: 55-57). ${ }^{11}$ Foresight means the ability to be free from particular biases and to discern how far the intended aim matches the overall goal of human life understood as ultimate goodness. Where these goals are narrowly portrayed in terms of the particular products of technology, then foresight is distorted. For example, does

${ }^{10}$ While Aquinas takes this list from A ristotle, biblical wisdom also includes similar ideas of memory and aptness to being taught (Proverbs 3:1), reason and understanding (Proverbs 2:5, 18:15) and ingenuity (Proverbs 8:30)

${ }^{11}$ These ideas are also found in instructions to those who wish to acquire wisdom in Proverbs, for circumspection, see Proverbs 14:8, for foresight and caution see Proverbs 14:16, $22: 3$ the introduction of vital vitamins to rice and other staple crops grown in the poorer nations of the world even begin to solve the problem of nutrition in these nations? A technological fix can only be a temporary and even partial solution; for it ignores the fact that world hunger is more often than not the result of economic and social problems. ${ }^{12}$ Even expecting multinational companies to solve the world food crisis is a failure of foresight, for it assumes that they will behave altruistically rather than be driven by market forces (Stewart 2002). Circumspection is the ability to attend to circumstances, and involves a clear perception of reality. For example, the possible ecological damage associated with genetically modified crops has not so far been adequately researched, since 'we do not have an adequate ecological understanding of the complex interactions engendered by releasing GM Os even into semi-natural ecosystems' (Walton 2000: 15). ${ }^{13}$ Finally, prudence also expresses caution, or avoiding obstacles. There are numerous examples in genetic technology where there are clear risks involved either to human health or the environment. Where these risks are exaggerated, this amounts to a distortion of practical wisdom. For example, the research published by $\mathrm{Dr}$ Arpad Pusztai claiming that a modified lectin gene causes adverse effects in rats was not subjected to normal peer review and scrutiny prior to publication (Deane-Drummond 2001: 65). Despite this, campaigners and the media have used his work to make irresponsible claims that genetic modification causes serious intestinal infection in rats, when in fact his research simply describes the structure of the small intestine (Dixon 2001:275).

The precautionary principle is commonly adopted by committees adjudicating on whether or not to approve particular developments in GM research and associ-

${ }^{12}$ Correcting one vitamin deficiency alone is likely to be of limited benefit because of the interaction between different vitamins and minerals needed for good health. While the researchers involved were in all probability well aware of this limitation, it is worth asking if the funding spent so far on such a development is really appropriate, given its limited value. Shiva has suggested that red rice growing naturally has about ten times the concentration of vitamin $\mathrm{A}$ compared with the 'golden rice' modified by genetic engineering. (Shiva 2002). Public consultation is critical if such developments are not going to be perceived as yet another form of neo-colonialism, however good the intentions. The virtue of foresight can serve to encourage such a wider perception, rather than limiting the consideration to one of isolated problem solving

${ }^{13}$ David Walton suggests, that if the funding was supported by the state then there might be greater public acceptance that 'objectives were really feeding the hungry and not greater dividends, and that the control and oversight mechanisms were robust enough to ensure that health and the environment would be protected as far as possible', Walton 2000:15 
ated environmental decisions. In this scenario we are left with the alternatives to adopt or reject the precautionary principle, along with difficulties of its definition. Instead, I suggest that precaution needs to be just one factor set in a much wider frame of practical wisdom, including the various elements indicated above. The lack of trust of governments on the part of the public is suggestive of alternative ways of framing decision-making that takes this suspicion into account (Deane-Drummond et al. 2001:23-24). Wisdom, as that which delves behind the attitudes of those making the decisions, is one possible step in the rebuilding of relationships that is so vitally needed.

\section{THE SIGNIFICANCE OF JUSTICE AS VIRTUE}

I indicated earlier that virtue of justice is an appropriate companion to prudence and wisdom in framing appropriate ethical action. The ancient sages were well aware of the link between justice and wisdom, indeed Proverbs personifies Lady Wisdom as one who 'By me monarchs rule and princes issue just laws; by me rulers govern and the great impose justice on the world' (Proverbs 8.16-17). In the monarchical society of the time, kingship, wisdom and justice were intertwined. A more appropriate framework for today is kinship, rather than kingship, but this shift need not deny the basic principle of linking justice and wisdom. Virtue ethicists have tended to associate justice with Kantian ethics, but for Aquinas justice is also a virtue to be acquired, alongside prudence or practical wisdom. ${ }^{14}$ Indeed when justice is defined in association with rights, it no longer makes logical sense to speak of justice towards future generations that is the premise of much environmental concern (Beckerman \& Pasek 2001:11-45). This means that additional ethical resources are required in order to elucidate obligations, and Beckerman \& Pasek are driven to hint at the possibility of virtue theory making a contribution in this respect. However it is not filled out in any detail and they seem to assume that justice is not a virtue (Beckerman \& Pasek 2001:24-25). Of course, unlike the other virtues, justice also has an objective basis through particular acts that could be characterised as just or not. In this sense justice moves away from virtue ethics sensus strictus in terms of agents and attitudes towards a more deontological position. ${ }^{15}$ In a similar way I indicated earlier that consequences are also taken into account in making prudential choices. This means that those following Kantian views can take into account some of the advantages gained through virtue

\footnotetext{
${ }^{14}$ Onora O'Neill combines a Kantian approach with virtue ethics, see O'N eill 1996
}

ethics, so I suggest that it is possible to incorporate ideas about what counts as justice without losing the emphasis on the importance of the virtues. In a just order, each is given his or her due. This once again raises the priority of consideration of the needs of the poor as well as consideration of non-human creatures and the wider environment. Beckerman \& Pasek predict that there will be continuing economic growth and this will have a trickle down effect on alleviation of basic environmental problems and poverty, though basic human rights remain untouched by economic trends (2001:89-106). Yet their assumption that acute problems associated with environment and poverty will become progressively ameliorated amounts to economic reductionism based on economic forecasts. In addition, they seem to assume that the demands of the environment and those of the poor are in some sense in competition for the same economic resources, while recognising that they do at times intersect. Clearly, the means of deciding which environmental problem takes priority over which particular demand from a human community is critical, but this is not discussed. It is one of the reasons why I suggest that justice needs to be aligned with practical wisdom, understood as discernment: once justice is considered to be a virtue it no longer has to be associated so closely with the language of rights. The human virtue of justice, understood in terms of human obligations, can take into account the importance of the non-human species as part of the overall ecological community.

What are the duties in relation to the 'others' in the community of life? Certainly, there may be legally binding actions that have to be undertaken, that are more based on particular objective rules, but also morally binding ones as well that are more closely aligned with attitudes of the agents. Even within the moral sphere it is possible to distinguish that which is dishonourable as opposed to that which is unseemly. The distinction between these various forms of justice as virtue can be illustrated as follows. Ten thousand hectares of genetically engineered cotton have been found growing in India in the Western state of Gujarat (J ayaraman 2001: 555). The cotton had been genetically engineered to resist the bollworm using a gene from Bacillus thuringiensis. This gene (Bt) acts like an insecticide in the plants, and they are no longer

\footnotetext{
${ }^{15}$ It could be argued that wisdom also, as a theological category, moves away from virtue ethics in the manner understood by most philosophers. However, my intention is not to simply imitate virtue ethics, but to draw on these insights and incorporate them into a theocentric ethic of wisdom. Such a theocentric ethic is less alienating compared with other deontological theological positions, as it resonates with the language of virtues and orientates discussion around agents first, prior to consideration of particular theological principles
} 
infected. The farmers purchased their seed from $\mathrm{Navb-}$ harat, a small company which originally purchased seed from Maharashtra Hybrid Seeds Company, M ahyco. M onsato have a $26 \%$ stake in the latter company and the seed is freely available for purchase in the USA. The row exploded because M onsanto discovered Bt cotton on farms on the Western state of Gujarat and they had not been paid for the patents. Navbharat could argue that it lacked the technology to detect transgenic strains. From a legal perspective the action of Navbharat is against the law, breaking the legal requirement to pay dividends for patents on particular 'inventions', in this case GM cotton. It is not clear if $M$ onsato had been granted an Indian patent on Bt cotton as the work with Mahyco was still at the field trial stage. M ahyco had spent US $\$ 8$ million on preparing to commercialise Bt cotton for the Indian market. In terms of business ethics $M$ ahyco/M onsato did have their particular 'rights' violated according to patent law. It is also worth asking how far the Indian regulatory system is able to ensure that the patent can be carried out in terms of monitoring the seed. Perhaps the Indian authorities were imprudent in granting a patent in the first place. From the perspective of justice in the widest sense it is possible to ask whether the multinational giant Monsanto is morally justified in making such demands for patent payments where it is doubtful if India would ever have the resources for adequate monitoring.

The practice of Western companies indulging in 'gene piracy' (i.e. the lifting of genetic resources from poorer nations and then imposing a patent on them), as well as the introduction of particular genetic traits such as 'terminator genes', serve to break down the trust between larger companies and our neighbours in the Southern nations of the world (Bruce \& Horrocks 2002: 132-134). ${ }^{16}$ Both Monsanto's attitude and their action could be said to be dishonourable in making demands for payments for patents from nations that can ill afford to do so. In addition, the imposition of patent law implies that frameworks adequate for an industrialised Western nation cannot be applied in a crude way to that of a poorer 'developing' community. It raises wider questions about the whole system of patenting as applied on an international level. Moreover what would be the social consequences for subsistent farmers growing traditional crops if agricultural practice shifted significantly towards commercial GMOs? The motivation of Monsanto in developing GM cotton for the Indian market was clearly commercial. If the officials on either side behaved in such as way as to express hostility or anger, then such an attitude could

${ }^{16}$ Vandana Shiva has called this kind of action 'piracy'. See Shiva 1998, 2001 be said to be unseemly. J ustice is violated in this case because it serves to break down relationships in a community. All acts of virtue relate in one sense or another to justice, hence Aquinas refers to justice as the 'most perfect virtue'. ${ }^{17}$ Devel oping cash crops specifically for use in the Indian subcontinent could be said to be an example of ecological injustice. The chairman of an Indian department of biotechnology committee has asked whether 'this is a foretaste of a frightening situation where transgenics will be out of control and all over the place'. ${ }^{18}$ Yet the 'solution' to this biotechnological problem is to press for Rs100 million to be spent on national laboratories to monitor GMOs. Given the reality of the shortage of funds for other work, is this a just use of resources?

The above example suggests that an act of justice can be judged, as it were, from the outside in an objective way. This makes justice different from the other virtues such as temperance or fortitude. Acts of justice are not necessarily affected by particular dispositions towards another; hence it is possible to act justly while not having an inner disposition towards justice. It may be that the Indian company mistakenly mixed up the seed used, but while this would be a legal injustice according to patent law, it would not render the company unjust. However, the ideal of justice as virtue requires both an inner assent to justice as well as an external just action. J ustice also reflects obligations to the community, hence in Aquinas's scheme it is ranked higher than other virtues such as temperance or fortitude that relate simply to inner dispositions.

While justice as virtue is the starting point for effective environmental decision-making, consideration of wider concerns of justice locates the virtue in the context of a particular way of thinking in an objective sense about just relationships. Aquinas divided the just ordering in community life to firstly that between individuals, or commutative justice; secondly to that between the whole and the individual or distributive justice; and thirdly that between the individual and social whole or legal justice (Pieper 1966:70-74). These distinctions follow from the fact that the kind of legal protection afforded by the state is different in kind to that which is due between individuals. The philosopher J osef Pieper criticises individualism in not taking sufficient account of the reality of the social whole in making just decisions (Pieper 1966:70-74). On the other hand, there is an opposite danger in collectivism, where no one individual enters a relationship in their own right. In this case no individual is given any right, and hence no due. The idea of justice

\footnotetext{
${ }^{17}$ I am drawing on the somewhat neglected work of the Roman Catholic philosopher, J osef Pieper (1966)
}

${ }^{18}$ Cited in J ayaraman 2001 
collapses. Some forms of deep ecology and Gaian thinking seem to lean far too heavily in this direction. Of course Aquinas' scheme fails to take into account the corporate nature of contemporary existence in so far as today, legally speaking, multinational companies have rights. Hence particular companies have particular responsibilities to act according to the law.

Commutative justice is what is owed to a stranger and follows what is due according to particular contracts. For all intents and purposes commutative justice could be said to apply to biotechnological companies in relation to individuals and their claims for particular demands for what is due in their case. The relationship between parties needs to be one of mutual respect, rather than hostility, so that the task of commutative justice is:

'to bring solace and order into the conflict of contending interests which by their nature are legitimate opposites and not easily reconcilable, to impose on them, as it were, a posterior order, is the office and task of commutative justice' (Pieper 1966:79).

In the case of GM Os the task of commutative justice would be to ensure that no damage exists to someone or their property as a result of the release of GMOs. However, where accidents happen, such as in the case of accidental contamination of organic farms during field trials of GMOs, then compensation would be required since some recompense needs to be made. Of course this presupposes that it is possible for GMO field trials to take place without any risk of contamination. Given the close proximity of different farming practices in countries such as the UK, this may not be feasible. In this scenario, it might be possible to argue for 'organic-free zones' as well as 'GM free zones'. The just person needs to recognise the wrong committed, admit to the injustice and endeavour to eradicate it. The problem in the case of organic farming is that both organic and non-organic farmers claim an equal right to practice farming according to particular principles, though an assessment of risk to organic farmers would seem to be prudent prior to approval of field trials.

The case of multinationals also crosses into a second area of justice, namely distributive justice, since this describes the relationship between those who have power and those who are in some sense 'delivered' to this power. Since biotechnology is governed largely by the work of multinationals plus in some cases central government, the responsibility for just action becomes one of distributive justice. The difference is that whereas in the classic understanding of distributive justice, what belongs to an individual is a share in what belongs to everyone, for multinationals, apart from its relationship to its own employees or stake holders, the individual has no share or part in its activities, except in so far as the flourishing of the company boosts the overall economy of the state as a whole.

Those who are guardians of the common weal calculate what is due to the individual in the case of distributive justice. For state rendered compensation, particular subjects of particular grievances are taken into account in a way that is not true of commutative justice. Yet where those who are responsible do not exercise their powers justly, then injustice reigns. Where the law of the state restrains multinationals to act responsibly towards individuals and the environment, then one can expect some measure of justice to ensue. However, what happens in those situations where state law is less regulated such as the relative lack of regulations on the safe use of chemicals, fertilisers and also genetically modified crops in the poorer nations of the world? According to a recent report 'developing countries have less well developed regulatory structures and expertise to manage the introduction of GM crops appropriately' (Nuffield Council on Bioethics 1999: 136). In this case justice relies on being exercised by the multinational companies towards strangers, in this case those living in such nations. The parties to the global convention on biodiversity (CBD) are trying to adopt a Biosafety Protocol. While this may act like 'a first line of defence' it relies on members being part of this wider global community. In these instances, international bodies also contribute to the working out of justice.

\section{CONCLUSIONS}

In addition to social and political considerations, I have argued that in order to uncover the reasons behind difficulties in environmental decision making we need to explore human attitudes and motivation. One attitude of particular significance is that of wisdom, for not only does it link with practical reason through prudence, but also from a theological perspective it joins with an understanding of the relationship between God, humanity and the world. In other words wisdom invites a theocentric perspective on ethics that does not exclude secular ethical considerations, but encompasses and critiques different secular alternatives. Given that I have argued for a recovery of Aquinas' way of approaching ethics, his views on practical wisdom and justice as virtues are also of particular importance. Prudence is the first of the cardinal virtues and serves to shape the way they develop. In other words, there can be no justice without prudence. J ustice is situated in the context of right relationships between God and the created world understood in terms of covenant. The nature of the relationships themselves can be described theologically in terms of 
wisdom. How might this work out in practical decisionmaking? I suggest that those who are responsible for making decisions have a responsibility to examine closely the attitudes and motivation of all contesting parties. In terms of raising environmental awareness and concern, wisdom reminds us of the importance of the created order, the need to consider the beauty and intricacy of creation, and hence is aligned to other virtues such as wonder and humility. A virtue ethic orientated on wisdom challenges the sufficiency of consequential approaches, while including the prudential discernment of consequences as integral to what it means to have virtue. For Christian believers such scrutiny of attitudes becomes part and parcel of Christian discipleship, since such decisions are consistent with what it means to inaugurate the reign of God and express God's wisdom. The Christian vision includes one of kinship with creatures, so that all creatures are not simply for instrumental human use, but are given respect as those that embody, to some degree, the wisdom of God.

In discussing the merits or otherwise of biotechnological change, justice between individuals and corporations is not simply definable in terms of breaking the law such as that covering patents, because there are moral aspects of justice that make particular attitudes and actions dishonourable. Yet justice requires prudential consideration of the alternatives before a claim can be made. In other words, the ability to see reality clearly - which is the province of practical wisdom leads to actions that affect human relationships with each other-which is the province of justice. This paper has attempted to delineate some of the ways in which wisdom and justice as virtues could facilitate environmental decision-making. I have argued that wisdom is integral to an understanding of who God is and thus needs to be reflected in the way humanity relates to each other and to the natural world. The search for wisdom is always incomplete, for it involves the shared search of the wider community of the public including theologians and scientists. I suggest that it is in and through such collaboration that respect for God and for each other develops. Perhaps we can say that this developing respect is the beginning of wisdom (Proverbs 1:1-7).

\section{LITERATURE CITED}

Aquinas T (1974) Summa Theologiae 2a2ae, Vol 36, Prudence, Qu. 48 Parts of Prudence, translated by T Gilby. Blackfriars, London

Bauckham R (2000) Stewardship and relationship. In: Berry RJ (ed) The care of Creation. IVP, Leicester, p 99-106

Bauckham R (2002) Voicing Creation's praise. Ecotheology 7.1:45-59
Beckerman W, Pasek J (2001) J ustice, posterity and the environment. Oxford University Press, Oxford.

Berry RJ (ed) (2000) The care of Creation: focusing concern and action. IVP, Leicester:

BMA (1999) The impact of genetic modification on agriculture, food and health: an interim statement. British Medical Association, London

Bruce D (2001) How far should we take the precautionary principle? Paper delivered to the British Ecology Society and the Linnean Society, April 26th 2001, Burlington House, London

Bruce D, Horrocks D (eds) (2001) Modifying Creation? GM crops and foods: a Christian perspective. Evangelical Alliance Policy Commission, London

Cessario R (2001) Introduction to moral theology. The Catholic University of America Press, Washington, DC

Christianson E (2002) The ethics of narrative wisdom: a test case. In: Brown W (ed) The character of Scripture: moral formation, identity, and ethics in the Bible. Eerdmans, New York (in press)

Crisp R, Slote M (1998) Virtue ethics. Oxford University Press, Oxford

Deane-Drummond C (2000) Creation through wisdom: theology and the new biology. T \& T Clark, Edinburgh

Deane-Drummond C (2001) Biology and theology today: exploring the boundaries. SCM Press, London

Deane-Drummond C (2002) Aquinas, wisdom ethics and the new genetics. In: Deane-Drummond C, Szerszynski B (eds) Re-ordering nature: theology, society and the new genetics. T \& T Clark/Continuum, Edinburgh (in press)

Deane-Drummond C (2003 The Logos as Wisdom: a starting point for a Sophianic theology of Creation. In: Clayton $\mathrm{P}$, Peacocke $A$ (eds) In whom we live and move and have our being: reflections on panentheism in a scientific age. Eerdmans, New York (in press)

Deane-Drummond C, Szerszynski B, Grove-White R (2001) Genetically modified theology. Studies in Christian Ethics (14):25-41

Dixon B (2001) Transgenic ills and otherwise: Review of Redesigning Life? In: Toker B (ed) The worldwide challenge to genetic engineering, N ature 412:275

J ayaraman K.S (2001) Illicit cotton sparks corporate fury. Nature 413:555

Habel, N (2002) The Book of J ob: Suffering and cognition in context, Paper delivered to the colloquium of the Royal Netherlands Academy of Arts and Sciences, A pril 22-23 2002

Hursthouse R (1999) On virtue ethics. Oxford University Press, Oxford

Huxham M, Sumner D (eds) (2000) Science and environmental decision making. Prentice Hall/Pearson Education, Edinburgh

J ohnson E (1992) She who is: the mystery of god in feminist theological Discourse. Crossroad, New York

Keenan J (1998) Virtue Ethics. In: Hoose B (ed) Christian ethics: an introduction. Cassell, London, p 84-94

Larkin L (2002) Face-to-face with Limobius mixtus, Ecotheology, 7.1:30-44

Lash S, Bronislaw S, Wynne B (1996) Risk, environment and modernity: towards a new ecology. Sage, London

Merritt J Q, J ones PC (2000) Science and environmental decision-making: The social context. In: Huxham M, Sumner $D$ (eds) Science and environmental decision making Prentice Hall/Pearson Education, Edinburgh, p 63-93

Midgley M (2001) Science and poetry. Routledge, London

Nasr S (1996) Religion and the order of nature. Oxford University Press, Oxford 
Northcott M (2002) Behold I have set the land before you. (Deut. 1.8): Christian Ethics, GM foods and the culture of modern farming. In: Deane-Drummond C, Szerszynski $B$ (eds) Re-ordering nature: theology, society and the new genetics. $\mathrm{T} \& \mathrm{~T}$ Clark/Continuum, Edinburgh (in press)

Nuffield Council on Bioethics (1999) Genetically modified crops: the ethical and social issues. Nuffield, London

O'Neill O (1996) Towards justice and virtue: a constructive account of practical reasoning. Cambridge University Press, Cambridge

Pieper J (1966). The four cardinal virtues. University of N otre Dame Press, Notre Dame

Ray J (1691/1977) The wisdom of God manifested in the

Editorial responsibility: R.J. (Sam) Berry,

London, United Kingdom works of creation. Arno Press, New York

Shiva V (1998). Biopiracy. Green Books, London

Shiva V (2001) Stolen Harvest: The hijacking of the global food supply. Zed Books, London

Shiva V (2002) Opening plenary. Workshop on life on a threatened planet: genetic controversy and environmental ethics, J une 4, 2002, Centre for Theology and the Natural Sciences, University of Berkeley, California, USA

Stewart J (2002) Reordering means and ends: Ellul and the New Genetics. In: Deane-Drummond C, Szerszynski B (eds) Re-ordering nature: theology, society and the new genetics. $T \&$ \& Clark/Continuum, Edinburgh (in press)

Walton D (2000) Genetically modified futures? Brit Ecol Soc Bull 31(2):14-16

Submitted: September 4, 2002; Accepted: September 7, 2002 Proofs received from author(s): September 23, 2002

Published on the web: September 26, 2002 